\title{
Developing and Validating Survey of Attitudes toward Web-Based Autonomous College English Learning
}

\author{
Huaikui Li \\ College of Foreign Studies, Guangxi Normal University, Guilin, China \\ Email: huaikuil@163.com \\ Received 28 April 2015; accepted 13 May 2015; published 25 May 2015 \\ Copyright (C) 2015 by author and OALib. \\ This work is licensed under the Creative Commons Attribution International License (CC BY). \\ http://creativecommons.org/licenses/by/4.0/

(c) (i) Open Access

\section{Abstract}

Attitude is one of the important affective factors mediating the SL/FL learning. Scholars, however, are divided as to what categories there are in it. This paper aims to develop and validate a survey of attitudes toward web-based autonomous college English learning (WBACEL). At the stage of pretesting, two teaching methodological experts were invited to have a first evaluation on the wording and format of the survey, and 20 items were suggested to delete. Then it is a small-scale pretesting; three more items without good enough discrimination were dropped out. Finally it is a large-scale pretesting; another ten items proved to be low correlated with the survey were deleted. At the stage of piloting, 283 valid questionnaires (out of total 318 students from nine regular classes) were collected and processed. From the results of item analysis (including item description, item discrimination analysis, and correlation analysis), and the test of construct validity, nine items were deleted. Factor analysis shows that the remaining 28 items can be divided into five attitudinal WBACEL factors: learning valence, resources and learning materials, learning plans and objectives, self-efficacy of learning, and evaluation of learning performance. The items of the whole questionnaire and those of each factor are consistent together with good indexes of Cronbach Alpha coefficient. The findings show a necessity to a reconceptualization of attitudes (in contrast to Gardner's attitudinal construct in AMTB) in the web-based foreign language learning contexts.

\section{Keywords}

College English Learners, The Development and Validation of Web-Based Autonomous College English Learning Attitude Survey (WBACELAS), Pretesting, Piloting

\section{Subject Areas: Education}




\section{Introduction}

The new College English Curriculum Requirements drawn up by the Ministry of Education [1] attaches great importance to network technology in the new teaching and learning mode, with the aims to change the Chinese students' learning habit perceived as syllabus dependent, passive and lacking in initiative (Pierson [2]) and to foster tertiary level non-English major students' individualized autonomous learning. A large number of universities, especially those 180 selected as the experimental ones in 2004 ${ }^{1}$, either used the online system designed specifically for the respective English textbooks such as New Horizon College English, New Concept College English, Experiencing English and New Era Interactive English or developed their own cyberspace English platform or center to conduct teaching and learning. Since then, the mode of web-based autonomous (WBA) learning of English has been on its way to gain popularity on campus in the Mainland China. Studies of readiness of school authority, teachers and learners in such mode of learning become a major branch of English teaching research, among which the studies of students' attitude toward WBA learning mode have been gaining more attention (Liang et al. [3], Zhu [4], Ruan \& Chen [5]).

The present paper designs a questionnaire to measure non-English major's attitude of WBA English learning and tests its reliability and validity quantitatively. First it is the literature review, looking at the studies on the relation between students' autonomous foreign language learning (FLL) attitudes toward web-based environment and those toward other FLL environments, and how researchers operationalized FLL autonomy (whether web-based or not) is also reviewed. Then the paper explains the procedure of data collection, including the sample selection, pretesting, pilot testing of the questionnaire and the way to analyze the data. Finally, the paper ends with discussing how the major findings are related to the results of the previous similar studies.

\section{Literature Review}

\subsection{Attitudes toward WBAFLL: How Different They Are from Those toward FLL in Other Contexts}

The environment of web-based (WB) FLL is believed to be beneficial to learners. Chapelle [6], for example, argues that it can provide an authentic context and the atmosphere of solidarity and equality. As a result, more interaction and negotiation between learners occurs because learners have to depend on themselves, thus achieving the goal of improving learner's L2 proficiency. Furthermore, WBFLL activity amongst non-native speakers can reduce anxiety, therefore increasing both learning motivation and responsibility, improving self-concept and cultural awareness (Stepp-Greany [7], Warschauer [8], Freiermuth \& Jarrell [9]). Some other researchers hold that WB L2 learning approach should be used more frequently in different language courses as it provides a large amount of useful language input and audio-visual resources, which can arouse students' interest and stimulate their learning effectively, and the learners can follow a more flexible pace to learn these materials (Deci \& Ryan [10], Ward \& Newlands [11], Ayres [12], Roed [13]).

From the above description, it can be asserted that WB language learning environment can provide a natural context for learner autonomy, but such autonomy needs to be developed or fostered systematically (Zhu [4]: 73). Thus, the learners' attitude toward such mode of learning is deserved to be studied. Attitude is a part or a factor in Gardner's [14] Attitude/Motivation Test Battery (AMTB). Some other researchers, however, insist that the construct of attitude should be expanded to a number of factors (see Deci et al. [15], Qin [16], Noels et al. [17], Taguchi, Magid \& Papi [18]). The instruments of these attitudinal studies in general sense may not apply to the survey of WBFLL attitude in the Chinese context. Therefore, Liang et al. [3], Zhu [4], Ruan \& Chen [5] and the researchers of some other sources ${ }^{2}$ develop their own instrument to measure the Chinese students' web-based autonomous college English learning attitude (WBACELA). Of these instruments, Zhu's [4] undergoes quantitative reliability and validity test and seems to be the most reliable one even though the information of how the instrument was piloted and the data of factor analysis were not presented.

\subsection{Survey of Attitudes toward WBAFLL: How It Is Operationalized}

As is mentioned above, more and more researchers tend to extend the notion of FLL attitude to include more

\footnotetext{
${ }^{1}$ See http://www.moe.gov.cn/publicfiles/business/htmlfiles/moe/s3857/201007/93342.html.

${ }^{2}$ See http://wenku.baidu.com/view/c28aa660783e0912a2162aa2.html, http://www.sojump.com/jq/1314062.aspx.
} 
factors or scales. The same is true for those studying the autonomous FLL attitude. Little [19] argues that learner autonomy grows out of the individual's acceptance of his or her own responsibility for learning. Little wood [20] further develops Little's view, defining learner autonomy as an independent capacity to make and carry out the choices which govern a learner's actions. This capacity depends on two main components: ability and willingness. Learners' ability and willingness assume responsibility for their learning to be at the core of the notion of autonomy. Willingness depends both on the motivation and the confidence to take responsibility for the choices required. It is evident that for Little wood, the construct of autonomous learning can be first operationalized into learner's ability and willingness and the latter is further divided into the factors of learning motivation and confidence. Holec [21] also defines learner autonomy as the ability to take charge of one's own learning. Taking charge of one's own learning is having ability and holding responsibility for all the decisions concerning all aspects of learning. He operationalizes the ability and responsibility into these five main areas: (a) determining learning objectives, (b) defining content and progressions, (c) selecting learning methods and techniques to be used, (d) monitoring the procedure of acquisition and (e) evaluating what has happened. In this view, attitudes translate into practice is a necessary precursor of autonomy. Zhu [4] adapts this operational definition of Holec's in his study of the WBACEL attitudes and behaviors. We think Holec's operationalization of learner autonomy as suitable for our research purpose and two more factors, based on the literatures, are added in our pool of variables, i.e. the role of the participants (see partly Gardner's [14] variable of instructor's role in his AMTB and Zhu's [4] teachers' and learners' role in his attitudinal construct) and the self-efficacy of WBA learning (see Cid, Grãnena \& Tragant [22], Qin \& Wen [23]). The research questions under investigation are as follows:

(a) To what extent the items in the web-based autonomous college English learning attitude survey (WBACELAS) are appropriate?

(b) What factors or scales of WBACEL attitude are there in the survey?

(c) To what extent the items (within factors and in total) in the survey are consistent?

The three questions are analyzed quantitatively. Question one is approached by item analysis (including item description and item discrimination analysis), and correlation analysis, question two by factor analysis and the third question by internal consistency reliability analysis (Cronbach Alpha coefficient).

\section{The Study}

\subsection{Designing Instrument and Choosing the Respondents}

Based on Zhu [4], Gardner [14], Holec [21], Cid, Grãnena \& Tragant [22], and Qin \& Wen [23] and still a variety of sources ${ }^{3}$, the first version of our questionnaire contains 70 items (except for 6 negatively worded ones ${ }^{4}$ ) distributing in seven attitudinal variables: (a) evaluative references to the valence of the Cyberspace English

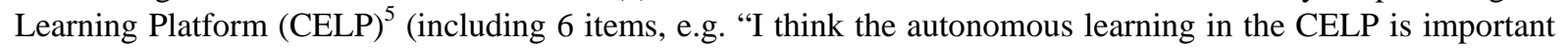
for me", "With the study in the CELP, I make progress in my ability to autonomous English learning"), (b) statements about the students' attitude toward WB learning resources and learning materials (including 33 items, e.g., "I feel satisfied with the software (such as whether the conversational windows are friendly to use, whether the materials are rich enough, whether there is teacher feedback and whether such feedback is on time and so on) of the CELP" and "I like the resources of the Tourism English Bank in the CELP”), (c) references to attitude toward role of the school authority, the teacher and peers (including 7 items, e.g. "I find it necessary to cooperate with my peer students to finish the online exercises assigned in the CELP" and "I think it is essential to have teacher's presence and guidance in our learning in the CELP”), (d) statements about their attitude toward English learning objectives and plans set for WBA learning (including 5 items, e.g. "I believe my arrangement of the time for the study in the CELP is proper" and "I think my goal set in the out-of-class learning in the CELP is practical”), (e) references to the attitude toward the WBA learning methods (including 7 items, e.g. "I think it necessary to seek help from the teacher of English when meeting troubles in the CELP" and "I believe it is essential to share my learning experience in the CELP with my peer students"), (f) evaluative attitudes toward self-efficacy of learning in CELP (including 5 items, e.g. "With the study in the CELP, I make progress in my listening skill" and "With the study in the CELP, I make progress in my oral English"), and (g) statements about

\footnotetext{
${ }^{3}$ See http://wenku.baidu.com/view/c28aa660783e0912a2162aa2.html, http://www.sojump.com/jq/1314062.aspx.

${ }^{4}$ These negatively worded items did not get processed in the later analysis.

${ }^{5}$ The platform was designed by Guangxi Normal University (GXNU), provided for both the in-class and out-of-class teaching and learning of the non-English majors.
} 
the attitudes of the means evaluating learning performance (including 7 items, e.g. "I think it practical to adopt the testing method like that of the final exam to measure my learning in the CELP" and "I believe it is proper to use the testing like unit quiz (that is, having a quiz after finishing a unit another two or three weeks) to evaluate my learning in the CELP"). These 70 items are presented in a Likert-scale format with the scale ranging "This statement is never or almost never true of me" to "This statement is completely or almost completely true of me". In some items, however, the scales are further specified. For example, in the item "I think the autonomous learning in the CELP is important for me", there are these scales: (a) This statement is never or almost never true of me because I spent less than 1 hour in the CELP each week and I only use the CELP to finish the assigned tasks, (b) This statement is usually not true of me because I spent 1 to 2 hours in the CELP each week and I mainly use the CELP to finish the assigned tasks, (c) This statement is sometimes true of me because I spent 2 to 4 hours in the CELP each week and I sometimes do the assigned tasks and sometimes deal with some other materials, (d) This statement is usually true of me because I spent 4 to 6 hours in the CELP each week and except for finishing the assigned tasks I still deal with some other materials and exercises, (e) This statement is completely or almost completely true of me because I spent more than 6 hours in the CELP each week and except for finish assigned tasks I still deal with other materials and exercises as much as possible. The language of the questionnaire is Mandarin Chinese.

The population of respondents is the third-term non-English majors. The reason to choose them as the participants is that by more than one academic year of using CELP. They may develop a mature or near mature opinion on the effectiveness of the virtual learning platform.

\subsection{Pretesting}

The wording and format of initial version of the questionnaire was first evaluated by two professors majoring in English teaching methodology who have been giving the applied linguistic courses to postgraduates of English major, one having the course of teaching methodology, and the other learning strategies. The attitudinal variable of self-efficacy was suggested to delete because it was thought to overlap with the first variable of CELP valence and its items are added to the valence variable. Totally 20 items recommended to be repetitive with those in other variables were deleted and some items were reworded. Of those items deleted, 16 are in the attitudinal variable of CELP resources and learning materials, two in the attitudinal variable of participant role, and another two in learning evaluation variable. As to the items reworded, for example, an item that was originally worded as "With the study in the CELP, I make progress in my ability to autonomous English learning" was reworded as "With the study in the CELP, I find the progress in my competence of autonomous English learning" because the former was not about one's attitude but fact of learning.

The 50-survey was then pretested on a small scale of ten students in the present author's class, who are from the same population. Five of them are male, the other five female. Among these respondents there are top, midand low-level students. The purpose of the pretesting is to find out: (a) the wording problem, (b) the problematic items. To achieve the first goal, we had one sentence in black on the top of each page of the questionnaire: "Please underline where you find awkward or difficult to understand". Some found “学伴” (peer students) in two items, for example, to be not natural. Therefore, it is reworded as “同班或者同宿舍同学” (classmates or roommates). As to the criteria of picking out problematic item, according to Dörnyei \& Taguchi [24], if an item is answered in the same way by almost everyone or by almost no one, it will not offer enough information from the sense of reliability. Therefore we delete those items answered in the same way by 70 percent of respondents. As a result, three items were deleted, one in the variable of learning method, the other two in the learning evaluation variable.

To further check the appropriateness of the survey, the 47-item questionnaire is conducted a second large scale pretesting. Some more negatively worded items (totally eight) are added behind their respective positively worded counterpart because they can pick out those uncooperative respondents in answering the questionnaire and these negative items do not go into the later data analysis. The administration was carried out in the first week of November in 2013 in the three regular classes of the present author ${ }^{6}$. The total number of students is 125, and questionnaires collected are 117 and 115 valid. To further find out problematic items quantitatively, a series of analyses is carried out: descriptive analysis, discrimination analysis and correlation analysis. First is the descriptive analysis. The item description shows no position response bias. The discrimination analysis through

${ }^{6}$ Ten students in one class answered in the first pretesting, and they were also asked to fill the questionnaire in this second pretesting. 
$\mathrm{T}$ test also does not tick out problematic items. To what extent a given item is proper can be also decided by looking at its coefficient (that is, how its mean score is correlated to the total mean score). Based on Qin [16]: 209, if the coefficient of an item is less than 0.3 , it is problematic. As a result, ten items are deleted, two of which are in resources and materials attitudinal variable, three in the attitudinal variable of participant role, four in learning method variable of attitude, and one in the attitudinal variable of learning evaluation ${ }^{7}$.

After the pretesting, the 70-item questionnaire is reduced to 37 items (see Table 1 for the items in each variable).

It is evident that the participant role attitudinal variable and the learning method attitudinal variable only have two items respectively. Anyway the pretesting helps effectively reduce the number of items so that they can be comfortably compiled within four A4 pages of a booklet of a questionnaire (Qin [16]: 124, Dörnyei [25]). From now on we will refer to the questionnaire as the initial WBACELAS (web-based autonomous college English learning attitudes survey). It consists of two parts. Part one centers on the subjects' attitudes toward WBACEL. There are 45 items, eight of which are negatively worded, and they are placed behind their respective counterpart. These negative items do not get processed in data analysis. Part two aims to acquire the subjects' personal information, including gender, background (from urban or rural middle school), campus, and major (as to the format, see my blog (http://huaikuil.blog.163.com) for the serial articles "The result of pretesting of WBACELAS”).

\subsection{Piloting}

\subsubsection{Data Collection}

The WBACELAS was administered to 318 students, most of whom completed the survey during class time in the last week of November in $2013^{8}$. These students are from nine classes. Four of them are on Campus A (centered on the arts), another four from Campus B (centered on the sciences), the last one class on Campus C. There is only one department (College of History and Tourism) on this campus. The detailed information is as follows in Table 2.

Those questionnaires will be deleted if fulfilling any of the following criteria: (a) more than half of the information not provided, (b) all items answered in the way, or (c) 60 percent of negatively worded items being answered quite contradictorily to their positively worded ones. As a result 35 questionnaires are invalid. All the data are entered into the SPSS database. The analysis involves a descriptive analysis, discrimination analysis and

Table 1. Item distribution in the variables of WBA learning attitude construct.

Attitudes towards CELP valence: 9 items

Attitudes towards WB resources and learning materials: 15 items

Attitudes towards participant roles: 2 items

Attitudes towards WBA learning objectives and plans: 5 items

Attitudes towards WBA learning method: 2 items

Attitudes towards evaluation of WBA learning performance: 4 items

Table 2. Number of questionnaires and their distribution.

\begin{tabular}{cccccccccccc}
\hline Classes & \multicolumn{4}{c}{ Campus A } & \multicolumn{4}{c}{ Campus B } & \multicolumn{3}{c}{ Campus C } \\
Questionnaires & Class 1 & Class 2 & Class 3 & Class 4 & Class 5 & Class 6 & Class 7 & Class 8 & Class 9 & Total \\
Collected & 36 & 34 & 31 & 28 & 40 & 40 & 42 & 28 & 39 & 318 \\
Valid & 35 & 31 & 22 & 25 & 37 & 37 & 35 & 25 & 36 & 283 \\
\hline
\end{tabular}

${ }^{7}$ For the detailed information of data, see the present author's blog (http://huaikuil.blog.163.com) for the serial articles "The result of pretesting of WBACELAS" (in Chinese).

${ }^{8}$ One teacher, seemed to have saved the time for his lecture, assigned the questionnaire to be filled out of class, and 28 questionnaires were collected out of 35 students. 
correlation analysis of each item, a construct validity test, and an internal consistency reliability test. The descriptive analysis, discrimination analysis and correlation analysis of each item allow us to detect if there are any problematic items before grouping them into different categories. The test for construct validity allows us to reduce the data by means of an exploratory factor analysis through the use of the principal components extraction and Varimax rotation methods. The test for internal reliability (Cronbach's Alpha) allows us to calculate the Cronbach Alpha levels for each factor and the whole items.

\subsubsection{Data Analysis}

The descriptive result of the items (only positively worded ones) is shown in the following Table 3.

Table 3 shows that no item obtains more than five percent of missing responses (see Cid, Grãnena \& Tragant [22] for the criteria), indicating that there seems to be no problematic items. The five levels in the response scale were used by the students and therefore a position response bias can be rejected.

The following Table 4 shows the data of item discrimination and item coefficients. In discrimination analysis, the $\mathrm{T}$ test of the respective 27 percent highest and lowest score of an item is conducted. In (Spearman) correlation analysis, the mean score of an item is correlated to that of the total items ${ }^{9}$.

From T-test, it seems that all (positively worded item) are not problematic. Correlation analysis reveals, however, that item 21, 29, 30, 39 and 40 are not proper because their Spearman coefficients are less than 0.3. Therefore, these five items are dropped in the following validity analysis.

Table 3. Descriptive measures: percentages, valid and missing of responses.

\begin{tabular}{|c|c|c|c|c|c|c|c|c|c|c|c|c|c|c|c|}
\hline \multirow{2}{*}{ Item } & \multicolumn{5}{|c|}{ Scale } & \multirow{2}{*}{ Valid } & \multirow{2}{*}{ Missing } & \multirow{2}{*}{ Item } & \multicolumn{5}{|c|}{ Scale } & \multirow{2}{*}{ Valid } & \multirow{2}{*}{ Missing } \\
\hline & $(1)^{*}$ & $(2)^{*}$ & $(3)^{*}$ & $(4)^{*}$ & $(5)^{*}$ & & & & (1) & (2) & (3) & (4) & (5) & & \\
\hline 1 & 19.4 & 29 & 39.6 & 10.2 & 1.4 & 282 & $1 / 0.4^{* *}$ & 22 & 8.1 & 14.8 & 36.6 & 30.6 & 9.5 & 282 & $1 / 0.4$ \\
\hline 2 & 19.1 & 33.2 & 24.4 & 16.3 & 2.5 & 270 & $13 / 4.6$ & 23 & 6.3 & 20.8 & 37 & 29.6 & 6 & 282 & $1 / 0.4$ \\
\hline 3 & 9.9 & 30.3 & 37 & 18.3 & 1.4 & 274 & $9 / 3.2$ & 25 & 9.9 & 26.4 & 43 & 16.9 & 2.5 & 279 & $4 / 1.4$ \\
\hline 4 & 25.7 & 37.7 & 25 & 9.5 & 1.8 & 282 & $1 / 0.4$ & 26 & 6.3 & 25.4 & 37.7 & 26.8 & 3.5 & 282 & $1 / 0.4$ \\
\hline 5 & 17.3 & 35.6 & 29.9 & 14.1 & 2.8 & 282 & $1 / 0.4$ & 28 & 7 & 16.2 & 35.9 & 28.5 & 12 & 282 & $1 / 0.4$ \\
\hline 6 & 20.4 & 36.6 & 29.6 & 10.9 & 2.1 & 282 & $1 / 0.4$ & 29 & 13.4 & 27.5 & 30.3 & 21.1 & 7.4 & 282 & $1 / 0.4$ \\
\hline 7 & 18.3 & 34.5 & 32.7 & 11.3 & 2.5 & 283 & 0 & 30 & 6.7 & 21.5 & 33.8 & 26.4 & 11.6 & 283 & 0 \\
\hline 8 & 20.1 & 32.7 & 32.4 & 11.3 & 1.8 & 281 & $2 / 0.7$ & 32 & 18.7 & 36.3 & 29.9 & 11.3 & 3.5 & 282 & $1 / 0.4$ \\
\hline 10 & 17.3 & 23.2 & 37.7 & 16.5 & 4.9 & 282 & $1 / 0.4$ & 34 & 11.6 & 30.3 & 45.4 & 10.2 & 2.5 & 283 & 0 \\
\hline 12 & 11.3 & 22.2 & 25.7 & 30.3 & 10.2 & 282 & $1 / 0.4$ & 35 & 12 & 34.2 & 39.4 & 11.3 & 2.8 & 282 & $1 / 0.4$ \\
\hline 13 & 18.3 & 34.9 & 24.6 & 16.2 & 3.5 & 276 & $7 / 2.5$ & 37 & 9.2 & 33.5 & 37 & 15.5 & 4.6 & 282 & $1 / 0.4$ \\
\hline 14 & 15.1 & 20.4 & 32.7 & 22.5 & 9.2 & 283 & 0 & 38 & 6.3 & 14.1 & 32 & 38 & 9.2 & 282 & $1 / 0.4$ \\
\hline 15 & 7 & 16.9 & 30.6 & 34.2 & 10.9 & 282 & $1 / 0.4$ & 39 & 5.3 & 9.5 & 24.6 & 39.1 & 20.1 & 279 & $4 / 1.4$ \\
\hline 16 & 16.2 & 29.6 & 30.6 & 17.3 & 6 & 282 & $1 / 0.4$ & 40 & 5.6 & 12.7 & 22.9 & 36.6 & 20.8 & 279 & $4 / 1.4$ \\
\hline 17 & 8.5 & 14.4 & 23.6 & 34.5 & 19 & 283 & 0 & 42 & 9.9 & 19.7 & 31 & 30.3 & 8.1 & 280 & 3/1.1 \\
\hline 18 & 15.1 & 21.8 & 28.5 & 27.5 & 6.7 & 282 & $1 / 0.4$ & 43 & 14.1 & 22.9 & 29.6 & 27.8 & 4.6 & 280 & $3 / 1.1$ \\
\hline 19 & 17.6 & 24.6 & 31.3 & 19.7 & 6.7 & 283 & 0 & 44 & 8.1 & 16.9 & 34.5 & 32.4 & 7 & 280 & 3/1.1 \\
\hline 20 & 12 & 18.3 & 31.3 & 27.1 & 10.9 & 282 & $1 / 0.4$ & 45 & 7 & 20.8 & 36.3 & 28.2 & 6.7 & 280 & 3/1.1 \\
\hline 21 & 4.6 & 8.1 & 16.9 & 36.6 & 33.8 & 283 & 0 & & & & & & & & \\
\hline
\end{tabular}

${ }^{*} 1$ = The statement is never or almost never true of me, $2=$ The statement is not true of me, $3=$ The statement is sometimes true of me, $4=$ The statement is true of me, 5 = The statement is totally or almost totally true of me; ${ }^{* *}$ The number behind “/” is percentage.

${ }^{9}$ We used Spearman correlation analysis because it applied to data whether they were normally distributed or not (Qin 2009: 210). 
Table 4. T-test of item discrimination and item coefficients.

\begin{tabular}{ccccccccc}
\hline Item & $\mathrm{T}$ & $\mathrm{R}$ & $\mathrm{Item}$ & $\mathrm{T}$ & $\mathrm{R}$ & $\mathrm{Item}$ & $\mathrm{T}$ & $\mathrm{R}$ \\
\hline 1 & $25.748^{* *}$ & $0.526^{* *}$ & 16 & $30.158^{* *}$ & $0.537^{* *}$ & 32 & $24.97^{* *}$ & $0.422^{* *}$ \\
2 & $29.155^{* *}$ & $0.649^{* *}$ & 17 & $30.83^{* *}$ & $0.471^{* *}$ & 34 & $21.111^{* *}$ & $0.435^{* *}$ \\
3 & $26.299^{* *}$ & $0.526^{* *}$ & 18 & $37.188^{* *}$ & $0.484^{* *}$ & 35 & $21.875^{* *}$ & $0.403^{* *}$ \\
4 & $32.552^{* *}$ & $0.536^{* *}$ & 19 & $37.23^{* *}$ & $0.595^{* *}$ & 37 & $24.758^{* *}$ & $0.427^{* *}$ \\
5 & $26.024^{* *}$ & $0.604^{* *}$ & 20 & $20.522^{* *}$ & $0.487^{* *}$ & 38 & $24.513^{* *}$ & $0.334^{* *}$ \\
6 & $26.46^{* *}$ & $0.59^{* *}$ & 21 & $30.467^{* *}$ & $\mathbf{0 . 2 4 2}^{* *}$ & 39 & $24.577^{* *}$ & $\mathbf{0 . 2 4 7}^{* *}$ \\
7 & $25^{* *}$ & $0.574^{* *}$ & 22 & $27.209^{* *}$ & $0.544^{* *}$ & 40 & $27.986^{* *}$ & $\mathbf{0 . 1 9 8}^{* *}$ \\
8 & $25.861^{* *}$ & $0.554^{* *}$ & 23 & $35.957^{* *}$ & $0.441^{* *}$ & 42 & $34.955^{* *}$ & $0.414^{* *}$ \\
10 & $29.334^{* *}$ & $0.458^{* *}$ & 25 & $25.118^{* *}$ & $\mathbf{0 . 3 9 1}$ & 43 & $37.53^{* *}$ & $0.411^{* *}$ \\
12 & $35.31^{* *}$ & $0.439^{* *}$ & 26 & $37.899^{* *}$ & $0.401^{* *}$ & 44 & $29.984^{* *}$ & $0.39^{* *}$ \\
13 & $28.468^{* *}$ & $0.512^{* *}$ & 28 & $27.978^{* *}$ & $0.398^{* *}$ & 45 & $35.534^{* *}$ & $0.368^{* *}$ \\
14 & $36.818^{* *}$ & $0.499^{* *}$ & 29 & $36.017^{* *}$ & $\mathbf{0 . 0 8 8}$ & & &
\end{tabular}

*** Difference or correlation is significant at 0.01 level (2-tailed).

The remaining 32 items are then subjected to principal components factor analysis to examine the internal structure. The factorability test of the data indicates a good factor analysis because the KMO value is 0.864 , exceeding the recommended value of 0.6 and the Barlett's Test of Sphericity reaches statistical significance $(\mathrm{p}=$ 0.000). From exploratory factor analysis and the interpretability of the resulting factors, a five-factor solution is most appropriate. These five factors accounts for 51.226 percent of the common variance ${ }^{10}$. The items with greater than 0.3 loadings determine the interpretation and labeling of the factors. The first factor receives appreciable loadings from 9 items and accounts for 15.017 percent of the common variance. This factor, including items $1,2,3,4,5,6,7,8$, and 10, falls exactly into the attitudinal variable of CELP valence in the initial WBACWLAS. Therefore, the factor can best correspond to the Attitudes toward WBA Learning Valence.

The second factor receives appreciable loadings from 10 items and accounts for 12.962 percent of the common variance. The items included in this factor are 12, 13, 14, 15, 16, 17, 18, 19, 22, and 28. They are in the attitudinal variable of CELP resources and learning materials in the initial WBACWLAS. This factor, therefore, can well correspond to Attitudes towards WB Resources and Learning Materials.

Factor three has appreciable loadings from 5 items and accounts for 8.594 percent of the common variance. This factor, including items 32, 34, 35, 37, and 38, falls exactly into the attitudinal variable of learning objectives and plans in the initial WBACWLAS. Therefore, this factor seems to well reflect a dimension of Attitudes toward WBA Learning Objectives and Plans.

Factor four receives appreciable loadings from 3 items and accounts for 7.372 percent of the common variance. The items included in the factor are 23, 25, and 26. It is separated from the attitudinal variable of WBA learning materials and resources in the initial WBACWLAS. The three items are respectively about the attitude toward the extent which CELP learning materials can help develop the English skills of listening, speaking and reading. This factor, therefore, can correspond to Attitudes toward WBA Learning Self-efficacy.

Factor five has appreciable loadings from 4 items and accounted for 7.282 percent of the common variance. This factor, including items 42, 43, 44, and 45, falls exactly into the attitudinal variable of WBA learning evaluation in the initial WBACWLAS. Therefore, this factor can best reflect a dimension of Attitudes toward the Evaluation of WBA Learning.

Moreover, based on Cid, Grãnena \& Tragant [22]: 503, an item can be deleted if it fulfills two or more of the dropping criteria: (a) it loads on more than one factor with similar loadings, (b) the loading is below 0.45, (c)

\footnotetext{
${ }^{10}$ The default 8-factor solution accounts for 61.599 percent of the common variance.
} 
there is another item in the survey with similar content, (d) there is a low index of correlation with the total score in a factor, or (e) there is a difficult interpretability of the item within a factor. Therefore, items 3,4 , and 5 in the first factor, and item 20 from factor four are deleted.

To examine the cohesion of the items, a test of reliability is carried out with the remaining 28 attitudinal items. As is shown in the Appendix, the corresponding Cronbach Alpha level of each of the five scales, except for the scale of attitude toward WBA learning evaluation, are above 0.7, and the Cronbach Alpha level of all 28 item is 0.8963. The results show that the items have good internal consistency.

Summing up, after the item analyses (including item description, discrimination, and correlation), validity and reliability tests conducted in this section, a total of nine items have been deleted and consequently in the final version of the WBACELAS, and there are now 28 items (see Appendix for details). These correspond to five factors with the following indexes of reliability. Factor I, labeled "WBA Learning Valence" attitude, refers to students' acknowledgement of the importance of WB autonomous English learning and the significance of such learning in the cultivation of one's study habit, ability to C-E or E-C translation and so on. This factor includes six items and has a Cronbach Alpha level of 0.8242. Factor II, labeled "WB Resources and Learning Materials" attitude, can be defined as the satisfaction of CELP software facilities and an interest in the materials of various sub-platform (such as those in the English Course Platform, Tourism English Bank, Yaxinda English Bank and so on). This factor includes 10 items and has a Cronbach Alpha level of 0.86. Factor III, labeled "WBA Learning Objectives and Plans" attitude, refers to an evaluative opinion on the time planned for the WBA learning, the appropriateness of such plans, the objectives and its effectiveness, and the monitoring of learning procedure. This factor includes five items and has a Cronbach Alpha index of 0.7604. Factor IV, labeled "WBA Learning Self-efficacy" attitude, is defined to be how CELP achieves one's goal in the cultivation of listening, speaking and reading skills. This factor includes three items and has a Cronbach alpha index of 0.7435. Finally, Factor V, labeled "Evaluation of WBA Learning" attitude, refers to students' opinion on how the WBA learning outcomes should be evaluated. This factor includes four items and has a Cronbach Alpha level of 0.6639.

\subsection{Discussion}

After the pretesting and the piloting, some change takes place for the questionnaire: (a) it is shortened to gain internal consistency and good discrimination of items, (b) the initial variables are restructured and redefined to gain validity. In this section we make a comparison between the initial variables with the final categories resulting from the validation, and how final categories are related with what previous studies found is also discussed.

All the nine items in the attitudinal variable "WBA Learning Valence" of the initial WBACWLAS have proved to load on one same construct (Factor I). However, three deleted items making reference to the assisting role of WBA learning to listening, speaking, and reading are repetitive with those in a new construct resulting from the factor analysis. Most items in the variable "attitude toward WB resources and learning materials" of the initial WBACWLAS also prove to load on one same construct (Factor II), but its three items are separated by factor analysis to form a new construct. All the remaining items in the attitudinal variable "WBA Learning plans and objectives" of the initial WBACWLAS have also proved to load on one construct (Factor III). Attitudinal factor IV "WBA Learning Self-efficacy" is a new construct, which was suggested to delete at the stage of expert assess of the questionnaire. The four remaining items in the attitudinal variable "Evaluation of WBA learning performance" of the initial WBACWLAS have proved to load on one same construct (Factor V). The attitudinal variables of "Participant Role" and "WBA learning method" in the initial WBACWLAS have dropped out by factor analysis. They are deleted mainly because a large proportion of their items are dropped out in pretesting by expert evaluation, item analysis, and correlation analysis (see Table 1).

Compared these factors with those published in previous research, a number of coincidences and departures can be found. Factor I "Attitude toward WBA Learning Valence" partly coincides with Gardner's [14] "Attitude” construct in his AMTB and Zhu's [4] attitudinal constructs of "Effectiveness of WAEL" and "Confidence in WAEL" in his investigation of WB learning attitude and behaviors because the construct includes items referring positive desire toward the importance of the learning and the environment, and the effectiveness of the learning. However, Gardner's construct is intended for language (French) learning in all types of environment and ours is specifically for the WB context. Moreover, our construct subsumes two variables of Zhu's as is mentioned.

Factor II labeled “Attitudes towards WB resources and Learning Materials” and factor V, labeled "Attitude 
toward Evaluation of WBA Learning” can be partially equated with Zhu's [4] variables "Choosing Learning Materials and Resources" and "Evaluating Learning Performance" respectively and are also categories found in some other studies such as Holec [21]. Factor III, "Attitude toward WBA Learning Objectives and Plans", is a construct also present in other survey studies such as Zhu's [4] "Formulating Learning Objectives and Plans" and Tremblay \& Gardner's [26] "Goal Salience”. The three variables of Zhu's, however, are in the behavioral construct and Tremblay \& Gardner's variable is in the construct of motivation.

The core concept of factor IV "Attitude toward WBA Learning Self-efficacy" can also be found in studies such as Qin \& Wen [23], Chambers [27], Graham [28], and Qin [29]. The term self-efficacy is preferred in the present study to the term self-confidence (such as Zhu's [4] name of his second variable of the attitudinal construct) because the latter is frequently used in association to L2 anxiety in the SLA literature. In factor IV, however, no item is present for the concept of anxiety.

\section{Conclusion}

This study is to elaborate a structured questionnaire to measure attitudes of WB autonomous English learning for the college non-English majors. After the stages of pretesting and piloting, the initial survey, which included 70 items and seven variables, has undergone several changes. It now includes 28 items which cluster into five factors (obtained by factor analysis) with good internal consistency. However, the questionnaire should never be taken granted as a valid instrument without validation in the subsequent studies. Firstly it is because the virtual college English learning center of most universities is school-based, and the present instrument may be subjected to some changes of items when used for similar research purpose. Secondly the validity of the factors will need to be confirmed in the subsequent studies where larger samples of college learners use WB mode of autonomous learning of English as a foreign language. In any case, the data in this study seem to be a necessity to a reconceptualization of attitudes (in contrast to Gardner's [14] attitudinal construct in AMTB) in the WB foreign language learning contexts.

\section{Funding}

This study was funded by the 2011 Projects of Educational Science in the Twelfth Five-Year Plan sponsored by the Educational Department of Guangxi Zhuang Autonomous Region, the serial number of project being $2011 Z Y 002$.

\section{References}

[1] The Ministry of Education of PR China (2004) College English Curriculum Requirements (for Trial Implementation). Foreign Language Teaching and Research Press, Beijing.

[2] Pierson, H.D. (1996) Learner Culture and Learner Autonomy in the Hong Kong Chinese Context. In: Pemberton, R., et al., Eds., Taking Control: Autonomy in Language Learning, Hong Kong University Press, Hong Kong.

[3] Liang, L., et al. (2007) A Survey of Autonomous English Learning by Non-English Majors. Journal of Xinjiang Medical University, 30, 1446-1447.

[4] Zhu, M. (2009) Web-Based Autonomous English Learning: An Investigation of Students' Attitudes and Behaviorurs. Teaching English in China-CELEA Journal, 32, 72-83.

[5] Ruan, X.F. and Chen, C.Y. (2011) Web-Based English Learning Attitudes, Motivations, Strategies and Habits: A Survey. Journal of Hubei Normal University, 31, 141-143.

[6] Chapelle, C. (1998) Lessons to Be Learned from Instructed SLA. Language Learning \& Technology, 2, 22-34.

[7] Stepp-Greany, J. (2002) Student Perceptions on Language Learning in a Technological Environment: Implications for the New Millennium. Language Learning \& Technology, 6, 165-180.

[8] Warschauer, M. (2000) On-Line Learning in Second Language Classroom: An Ethnographic Study. In: Warschauer, M. and Kern, R., Eds., Network-Based Language Teaching: Concepts and Practice, Cambridge University Press, Cambridge, 41-58.

[9] Freiermuth, M. and Jarrell, D. (2006) Willingness to Communicate: Can On-Line Chat Help? International Journal of Applied Linguistics, 162, 190-213.

[10] Deci, E.L. and Ryan, R.M. (1985) Intrinsic Motivation and Self-Determination in Human Behavior. Plenum, New York. http://dx.doi.org/10.1007/978-1-4899-2271-7 
[11] Ward, M. and Newlands, D. (1998) Use of the Web in Undergraduate Teaching. Computers \& Education, 31, 171-184. http://dx.doi.org/10.1016/s0360-1315(98)00024-4

[12] Ayres, R. (2002) Learner Attitudes toward the Use of CALL. Computer Assisted Language Learning, 15, $241-249$. http://dx.doi.org/10.1076/call.15.3.241.8189

[13] Roed, J. (2003) Language Learner Behavior in a Virtual Environment. Computer Assisted Language Learning, 16, 155-172. http://dx.doi.org/10.1076/call.16.2.155.15880

[14] Gardner, R.C. (1985) Social Psychology and Second Language Learning: The Role of Attitude and Motivation. Edward Arnold, London.

[15] Deci, E.L., Vallerand, R.J., Pelletier, L.G. and Ryan, R.M. (1991) Motivation and Education: The Self-Determination Perspective. The Educational Psychologist, 26, 325-346. http://dx.doi.org/10.1080/00461520.1991.9653137

[16] Qin, X.Q. (2009) Questionnaire Research in Foreign Language Teaching. Foreign Language Teaching and Research Press, Beijing.

[17] Noels, K.A., Clément, R. and Pelletier, L.G. (2001) Intrinsic, Extrinsic, and Integrative Orientations of French Canadian Learners of English. The Canadian Modern Language Review, 57, 424-442. http://dx.doi.org/10.3138/cmlr.57.3.424

[18] Taguchi, T., Magid, M. and Papi, M. (2009) The L2 Motivational Self System among Japanese, Chinese, and Iranian Learners of English: A Comparative Study. In: Dörnyei, Z. and Ushioda, E., Eds., Motivation, Language Identity and the L2 Self, Multilingual Matters, Bristol, 66-97.

[19] Little, D. (1996) The Politics of Learner Autonomy. Language Learning, 2, 7-10.

[20] Littlewood, W. (1996) “Autonomy”: An Anatomy and a Framework. System, 24, 427-435.

[21] Holec, H. (1981) Autonomy and Foreign Language Learning. Pergamon Press, Oxford.

[22] Cid, E., Grãnena, G. and Tragant, E. (2009) Constructing and Validating the Foreign Language Attitudes and Goals Survey (FLAGS). System, 37, 496-513. http://dx.doi.org/10.1016/j.system.2009.02.014

[23] Qin, X.Q. and Wen, Q.F. (2002) The Internal Structure of EFL Motivation at Tertiary Level in China. Foreign Language Teaching and Research, 34, 51-58.

[24] Dörnyei, Z. and Taguchi, T. (2011) Questionnaires in Second Language Research: Construction, Administration, and Processing. 2nd Edition, Foreign Language Teaching and Research Press, Beijing.

[25] Dörnyei, Z. (2003) Questionnaires in Second Language Research: Construction, Administration, and Processing. Lawrence Erlbaum Associations, Mahwah.

[26] Tremblay, P.F. and Gardner, R.C. (1995) Expanding the Motivation Construct in Language Learning. The Modern Language Journal, 79, 505-518. http://dx.doi.org/10.1111/j.1540-4781.1995.tb05451.x

[27] Chambers, G. (2000) Motivation and Learners of Modern Languages. In: Green, S., Ed., New Perspectives on Teaching and Learning Modern languages, Multilingual Matters Ltd., Clevedon.

[28] Graham, S.J. (2004) Giving up on Modern Foreign Languages? Students' Perception of Learning French. The Modern Language Journal, 88, 171-191. http://dx.doi.org/10.1111/j.0026-7902.2004.00224.X

[29] Qin, X.Q. (1998) An Investigation into the Internal Structure of EFL Motivation at the Tertiary Level in China. Ph.D. Dissertation, Nanjing University, Nanjing. 


\section{Appendix}

Results of factor analysis and internal consistency analysis of WBACELAS items: Rotated Eigenvalues and Cronbach Alpha Coefficients ( $a$ )

\begin{tabular}{|c|c|c|}
\hline Factor & Item & Eigenvalue \\
\hline \multirow{9}{*}{$\begin{array}{l}\text { I: Attitude } \\
\text { toward WBA } \\
\text { Valence } \\
(\text { a= } 0.8242 \\
(6 \text { items }))\end{array}$} & $\begin{array}{l}\text { 7、通过大学英语教学平台的英语学习, 我感觉自己的英汉互译的水平得到了提高。 } \\
\text { (I found to have made progress in my proficiency of English-Chinese translation through the online } \\
\text { learning in the Cyberspace English Learning Platform (CELP).) }\end{array}$ & 0.803 \\
\hline & $\begin{array}{l}\text { 5、通过大学英语教学平台的学习, 我觉得自己的阅读水平得到了提高。 } \\
\text { (I found to have made progress in my English reading through the online learning in the Cyberspace } \\
\text { English Learning Platform (CELP).) }\end{array}$ & 0.791 \\
\hline & $\begin{array}{l}\text { 6、通过大学英语教学平台的学习, 我感觉自己的写作水平得到了提高。 } \\
\text { (I found to have made progress in my English writing through the online learning in the Cyberspace } \\
\text { English Learning Platform (CELP).) }\end{array}$ & 0.779 \\
\hline & $\begin{array}{l}\text { 4、通过大学英语教学平台的学习, 我感觉自己的口语水平得到了提高。 } \\
\text { (I found to have made progress in my oral English through the online learning in the Cyberspace English } \\
\text { Learning Platform (CELP).) }\end{array}$ & 0.764 \\
\hline & $\begin{array}{l}\text { 2、在大学英语教学平台的帮助下, 我发现自己的自主学习能力提高了。 } \\
\text { (I found to have developed better habit of autonomous English learning with the help of the Cyberspace } \\
\text { English Learning Platform (CELP).) }\end{array}$ & 0.693 \\
\hline & $\begin{array}{l}\text { 3、通过大学英语教学平台的学习, 我感觉自己的听力水平得到了提高。 } \\
\text { (I found to have made progress in my English listening through the online learning in the Cyberspace } \\
\text { English Learning Platform (CELP).) }\end{array}$ & 0.647 \\
\hline & $\begin{array}{l}\text { 1、我发现大学英语教学平台的自主学习对于自己来说是重要的。 } \\
\text { (I found it important to do autonomous English learning in the Cyberspace English Learning Platform } \\
\text { (CELP).) }\end{array}$ & 0.59 \\
\hline & $\begin{array}{l}\text { 8、在大学英语教学平台的帮助下, 我觉得自己找到了学好英语的办法。 } \\
\text { (I found to have cultivated better ways to learn English with the help of the Cyberspace English Learning } \\
\text { Platform (CELP).) }\end{array}$ & 0.549 \\
\hline & $\begin{array}{l}\text { 10、我喜欢大学英语教学平台布置的作业。 } \\
\text { (I like the homework assigned in the Cyberspace English Learning Platform (CELP).) }\end{array}$ & 0.398 \\
\hline \multirow{8}{*}{$\begin{array}{l}\text { II: Attitudes } \\
\text { towards WB } \\
\text { resources and } \\
\text { learning } \\
\text { materials } \\
(a=0.8421 \\
(10 \text { items }))\end{array}$} & $\begin{array}{l}\text { 17、我喜欢大学英语教学平台空中英语课堂里的各项资源(即关于各种口语训练、四六级讲座、戏 } \\
\text { 剧节目视频和电影视频, 等等的资源)。 } \\
\text { (I like the materials from the data bank of Space Classroom in the Cyberspace English Learning Platform } \\
\text { (CELP) (e.g. those for English oral practice, tutoring CET } 4 \text { and CET 6, and the video of films and TV } \\
\text { programs).) }\end{array}$ & 0.71 \\
\hline & $\begin{array}{l}\text { 16、我喜欢大学英语教学平台中东盟主题英语的资源。 } \\
\text { (I like the English materials in the data bank introducing the ASEAN countries in the Cyberspace English } \\
\text { Learning Platform (CELP).) }\end{array}$ & 0.699 \\
\hline & $\begin{array}{l}\text { 15、我喜欢大学英语教学平台精品课程资源中的各项内容(即包括听说和读写课本的网络教学平台、 } \\
\text { 教师和管理员上传的各种教案和课件、学习方法指导、自主学习、分级分项训练、英美文化知识和 } \\
\text { 文学作品, 等等的资源。 } \\
\text { (I like the English materials of data bank of the Excellent Course in the Cyberspace English Learning } \\
\text { Platform (CELP) (e.g. the virtual platform of listening (including speaking) textbook and reading } \\
\text { (including writing) textbook, the teaching plans, tutoring of English (autonomous) learning), exercises } \\
\text { for all levels, introduction of English cultures and literature.) }\end{array}$ & 0.649 \\
\hline & $\begin{array}{l}\text { 14、我喜欢大学英语教学平台雅信达资源库中的各项内容。 } \\
\text { (I like the English materials from the Yaxinda data bank in the Cyberspace English Learning Platform } \\
\text { (CELP).) }\end{array}$ & 0.621 \\
\hline & $\begin{array}{l}\text { 13、我喜欢大学英语教学平台中的旅游主题英语的资源(即以听力形式呈现的关于桂林的一些风景 } \\
\text { 点的知识和相关练习)。 } \\
\text { (I like the English materials from the data bank of Tourist English in the Cyberspace English Learning } \\
\text { Platform (CELP) (e.g. the listening English about some of the Guilin scenic spots).) }\end{array}$ & 0.606 \\
\hline & $\begin{array}{l}\text { 18、我喜欢大学英语教学平台中的录音配音功能(包括录音模仿和配音练习)。 } \\
\text { (I like the software of English recording and dubbing in the Cyberspace English Learning Platform } \\
\text { (CELP).) }\end{array}$ & 0.587 \\
\hline & $\begin{array}{l}\text { 19、我喜欢大学英语教学平台师生互动平台中的各种功能。 } \\
\text { (I like the functions offered in the Cyberspace English Learning Platform (CELP) for teacher-student } \\
\text { interaction.) }\end{array}$ & 0.568 \\
\hline & $\begin{array}{l}\text { 12、对于学校现在网络自主学习方面提供的软件设施(如平台操作的方便性、系统资源的丰富性、 } \\
\text { 教师的在线反馈及其及时性, 等), 我感到满意。 (I am satisfied with the software facilities in the } \\
\text { Cyberspace English Learning Platform (CELP) (i.e. the friendliness of the platform, the rich materials, the } \\
\text { timely feedback of the teacher).) }\end{array}$ & 0.508 \\
\hline
\end{tabular}


28、对于大学英语教学平台提供的与四六级考试相关的训练材料, 我感到满意。

0.49

(I am satisfied with the CET4 and CET6 materials offered in the Cyberspace English Learning Platform

(CELP).)

22、我觉得大学英语教学平台中英语文化方面的知识对自己英语水平的提高有帮助。

0.426

(I found it helpful to improve my English after learning the knowledge of English culture offered in the

Cyberspace English Learning Platform (CELP).)

35、在平台的英语自主学习中, 我觉得自己所制定的计划(比如英语网络学习学习时间的安排)合适。0.824

(I found my plans for autonomous learning (i.e. the time assigned to online learning) in the Cyberspace

English Learning Platform (CELP) are appropriate.)

34、在平台的英语自主学习中, 我认为自己对所设定的学习目标(比如每一次学习的量和成绩上要 0.737

III: Attitude 达到什么样的程度)合适。

toward WBA (I found my objectives for autonomous learning (i.e. how much to learn and how well it is learned) in the

learning Cyberspace English Learning Platform (CELP) are appropriate.)

objectives and 37、在平台的英语自主学习中, 我认为自己对学习进度的控制是合适的。

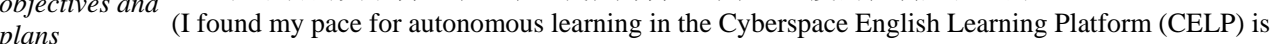

( $a=0.7604 \quad$ appropriate.)

$(a=0.7604$
$(5$ items $))$ 3 、我觉得自己根据不同的情况而调整平台英语学习的做法合适。

38、我觉得自己根据不司的情况而调整平台英语学习的做法合适。
(I found my flexibility for autonomous learning (the improvement of both time and objective) in the

Cyberspace English Learning Platform (CELP) is appropriate.)

32、我认为自己对课后的平台英语学习的时间安排合适。

(I found my after-class time planned for English learning in the Cyberspace English Learning Platform (CELP) is appropriate.)

26、我对大学英语教学平台中提供的材料对于自己阅读技能的帮助感到满意。

(I am satisfied with the CELP materials which is helpful to cultivate my English reading skills.)

IV: Attitude toward WBA 25、我对大学英语教学平台中提供的材料对于自己口语技能的帮助感到满意。

0.724

learning (I am satisfied with the CELP materials which is helpful to cultivate my English oral skills.)

self-efficacy 23、我对大学英语教学平台中提供的材料对于自己听力技能的帮助感到满意。

0.594

.

0.53

( $a=0.7435$ (I am satisfied with the CELP materials which is helpful to cultivate my English listening skills.)

(3 items)) 20、我喜欢大学英语教学平台的在线测试功能。

(I like the online test or quiz offered in the Cyberspace English Learning Platform (CELP).)

43、我觉得采用单元测试的办法(即每上完一单元就布置一次在线测试)衡量网络英语自主学习的效 0.755

果是可行的。

(I found it practical to measure the autonomous English learning by the unit quiz (i.e. to have an online

$V$ : Attitude quiz after students study one unit).)

toward WBA 42、我认为采用期末综合考试的办法衡量网络英语自主学习的效果是可行的。

learning (I found it practical to measure the autonomous English learning by the final exam.)

evaluation

44、我觉得通过建立学生电子学习档案记录的办法(如对所学网络资料的收集、学习总结及相应的

0.699

$(a=0.6639$ 技能练习作业)来衡量英语自主学习效果是可行的。

(4 items) (I found it practical to measure the autonomous English learning by taking the students' learning records (i.e. to what extent they collect the learning materials, their summary of the learning experiences and the assignments).)

45、我认为通过自我评价及同学评价的办法来衡量英语自主学习效果是合适的。

0.774

0.75

0.623

(I found it practical to measure the autonomous English learning by self evaluation and peer evaluation.)

$a$ of overall items $=0.8963$ (28 items). Key: Items 3, 4, 5 and 20 are deleted from the final version of WBACELAS. 